\title{
PENERAPAN MODEL PEMBELAJARAN KOOPERATIF TIPE MAKE A MATCH UNTUK MENINGKATKAN HASIL BELAJAR MATEMATIKA SISWA KELAS IV SD NEGERI 2 GAYAU SAKTI TAHUN PELAJARAN 2014/2015
}

\author{
Soleha \\ SD Negeri 2 Gayau Sakti \\ Email: yiswahyudi98@yahoo.com
}

\begin{abstract}
The aims of this research were to increase the student learning outcomes by implementation of cooperative learning model of Make A Match. The method of the research was Classroom Action Reserach. The data collected by the observation sheet, formatif test sheet (test student learning outcomes). The results of the study implementation of cooperative learning model of Make A Match proven to improve learning performance followed by increased the student learning outcomes, enthusiastic students to participate in learning. The result showed that Percentage student learning outcomes $41.6 \%$ in the first cycle to $93.3 \%$ in the second cycle.
\end{abstract}

Keywords: student learning outcomes, cooperative learning model of Make A Match

\section{PENDAHULUAN}

Pendidikan nasional berfungsi mengembangkan kemampuan dan mencerdaskan kehidupan bangsa bertujuan untuk berkembangnya potensi peserta didik agar menjadi manusia beriman dan bertaqwa kepada Tuhan Yang Maha Esa, berahlak mulia, sehat, berilmu, cakap, kreatif, dan mandiri menjadi warga negara yang demokratis serta tanggung jawab, Undang-Undang Sisdiknas No 20 tahun 2003.

Upaya untuk memajukan suatu kehidupan bangsa dan negara sesuai dengan tujuan yang telah dirumuskan maka didalamnya terjadi proses pendidikan atau proses belajar mengajar akan memberikan pengertian pada pandangan dan penyesuaian bagi seseorang atau si terdidik kearah kematangan dan kedewasaan. Dengan proses ini akan membawa pengaruh terhadap perkembangan jiwa dan potensi seseorang peserta didik kearah yang lebih dinamis baik terhadap bakat atau pengalaman, moral, intelektual, maupun fisik.

Satu hal yang penting yaitu guru sebagai pelaksana langsung pencapaian tujuan pembelajaran perlu meningkatkan kualitas 
proses pembelajaran yaitu dengan memperhatikan bagaimana cara menyampaikan pengetahuan yang dimiliki itu kepada peserta didiknya. Maka dari itu peneliti mencoba untuk melakukan penelitian tindakan kelas dalam mengatasi masalah tersebut.

Berdasarkan hasil observasi (pengamatan) ketika pembelajaran matematika berlangsung diperoleh data bahwa siswa kelas IV SDN 2 Gayau Sakti, kurang aktif dalam merespon pelajaran yang diberikan. Sehingga hasil belajar yang dicapai belum bisa dikategorikan "berhasil" karena belum mencapai $\mathrm{kkm}$ yang ditentukan yaitu 60. Adapun data hasil belajar siswa kelas IV SDN 2 Gayau Sakti dapat dilihat pada tabel sebagai berikut:

Tabel 1. Nilai Mid Semester Matematika Kelas IV SD Negeri 2 Gayau Sakti Tahun Pelajaran 2014/2015.

\begin{tabular}{|c|l|l|c|c|}
\hline No & Nilai & \multicolumn{1}{|c|}{ Kategori } & Jumlah & Persentasi \\
\hline 1 & $\geq 60$ & Tuntas & 5 & 29,41 \\
\hline 2 & $<60$ & Tidak Tuntas & 12 & 70,59 \\
& & 17 & \\
\hline \multicolumn{3}{|c|}{ Jumlah } & 17 \\
\hline
\end{tabular}

Sumber: Buku Daftar Nilai Mid Semester Siswa Kelas IV Semester SD Negeri 02 Gayau Sakti Tahun Pelajaran 2014/2015

Berdasarkan Tabel 1 di atas, terlihat bahwa siswa yang memperoleh $\geq 60$ sebanyak 5 siswa dari 17 siswa, artinya hanya $29,41 \%$ siswa yang telah mencapai ketuntasan dalam belajar. Sementara siswa yang memperoleh nilai $<60$ sebanyak 12 siswa dari 17 siswa, yang berarti bahwa 70,59\% siswa belum mencapai ketuntasan belajar. Sementara itu standar klasikal yang disepakati pihak sekolah adalah $60 \%$ dari jumlah siswa telah memperoleh nilai $\geq 60$. Dari tabel di atas dan penjelasannya bahwa siswa kelas IV semester genap belum mencapai ketuntasan belajar.
Berdasarkan pemaparan masalah di atas, maka penulis berpendapat bahwa perlu dilakukan perbaikan pembelajaran. oleh karena itu akan dilakukan penelitian tindakan kelas dengan judul "Penerapan Model Pembelajaran Kooperatif Tipe Make A Match Untuk Meningkatkan Hasil Belajar Matematika Siswa Kelas IV SD Negeri 2 Gayau Sakti Tahun Pelajaran 2014/2015". Dengan upaya ini diharapkan materi pelajaran dapat mudah dimengerti dan dipahami oleh siswa sehingga hasil belajar akan meningkat.

Model pembelajaran Kooperatif Make a Match 
(mencari pasanga) adalah system pembelajaran yang mengutamakan penanaman kemampuan sosial terutama kemampuan bekerja sama, kemampuan berinteraksi, disamping kemampuan berfikir cepat melalui permainan mencari pasangan dengan bantuan kartu (Wahab, 2007:59). Model pembelajaran make a match atau mencari pasangan merupakan salah satu alternatif yang dapat diterapkan kepada siswa. Penerapan model pembelajaran ini dimulai dari teknik yaitu siswa disuruh mencari pasangan kartu yang merupakan jawaban/soal sebelum batas waktunya, siswa yang dapat mencocokkan kartunya diberi point. Model pembelajaran Make A Match atau mencari pasangan dikembangkan oleh Curran (1994).

Salah satu keunggulan model adalah ini adalah siswa mencari pasangan sambil belajar mengenai suatu konsep atautopik dalam suasana yang menyenangkan. Suyatno (2009:72) mengungkapkan bahwa model pembelajaran Make A Match adalah model pembelajaran dimana guru menyiapkan kartu yang berisi soal atau masalah dan menyiapkan kartu jawaban kemudian siswa mencari pasangan kartunya. Model pembelajaran Make A Match merupakan bagian dari pembelajaran kooperatif. Model pembelajaran kooperatif didasarkan atas falsafah homo homini socius, falsafah ini menekankan bahwa manusia adalah makhluk social (Lie, 2003 : 27).

Tujuan dari pembelajaran dengan model Make A Match adalah untuk melatih peserta didik agar lebih cermat dan lebih kuat pemahamannya terhadap suatu materi pokok (Fachrudin, 2009 : 168). Siswa dilatih berfikir cepat sambil menganalisis sambil berinteraksi sosial.

\section{METODE PENELITIAN}

Penelitian ini adalah jenis Penelitian Tindakan Kelas (PTK). Menurut Arikunto (2006:2) penelitian tindakan kelas adalah sebuah kegiatan penelitian yang dilakukan di kelas.

Subyek penelitian ini adalah siswa kelas IV SDN 2 Gayau Sakti, Kecamatan Seputih Agung Kabupaten Lampung Tengah. Dengan jumlah siswa 17 orang, laki-laki 10 orang dan 7 orang perempuan. Menurut Arikunto (2006:16) model penelitian tindakan kelas dalam satu siklus terdiri dari perencanaan (planning), pelaksanaan (acting), pengamatan (observing), Refleksi (reflecting).

Penelitian tindakan kelas ini terdiri dari dua siklus. Setiap siklus. Setiap siklus akan diadakan perubahan pelaksanaan sesuai dengan faktor yang ingin diteliti. 


\section{HASIL PENELITIAN DAN PEMBAHASAN}

Setelah diadakan penelitian pada siklus I masih belum menunjukkan hasil yang memuaskan bahwa kemampuan siswa dalam memahami materi pembelajaran, Hasil belajar siswa serta pemahaman terhadap materi pembelajaran masih kurang maksimal. Dari hasil tes diperoleh nilai rata-rata 41,6. Nilai ini belum mencapai standar SKM yang ditetapkan di SD Negeri 2 Gayau Sakti, Kecamatan Seputih Agung Kabupaten Lampung Tengah.Untuk lebih jelasnya dapat dilihat pada Tabel 2. sebagai berikut:

Tabel 2. Hasil belajar matematika siswa kelas IV sebelum siklus dan siklus I

\begin{tabular}{|l|l|c|c|}
\hline No & Nama siswa & $\begin{array}{c}\text { Sebelum } \\
\text { siklus }\end{array}$ & $\begin{array}{c}\text { Nilai } \\
\text { siklus I }\end{array}$ \\
\hline 1 & Ade Revaldo & 30 & 60 \\
\hline 2 & Ambar Puspi & 60 & 40 \\
\hline 3 & Aliya Rizki R. & 40 & 70 \\
\hline 4 & Bangkit & 65 & 70 \\
\hline 5 & Catur Aji P. & 65 & 65 \\
\hline 6 & Ivan Tama W. & 20 & 40 \\
\hline 7 & Meli Agustina & 34 & 50 \\
\hline 8 & Manda K. & 65 & 50 \\
\hline 9 & M.Tegar P. & 20 & 30 \\
\hline 10 & Nur Wahid & 10 & 20 \\
\hline 11 & Rizki A. & 20 & 30 \\
\hline 12 & Vircius C. & 20 & 30 \\
\hline 13 & Siti M. & 40 & 50 \\
\hline 14 & Sandi Pratama & 10 & 20 \\
\hline 15 & Nicolas G. N. & 20 & 30 \\
\hline 16 & Ajeng Dwi S. & 20 & 30 \\
\hline 17 & Suyatno & 10 & 20 \\
\hline
\end{tabular}

Ketuntasan kelas $=$

jumlah siswa yang tuntas $\mathrm{x} 100 \%$ Jumlah total siswa

$\begin{aligned} \text { Ketuntasan kelas } & =\frac{8}{17} \times 100 \% \\ & =41,6\end{aligned}$

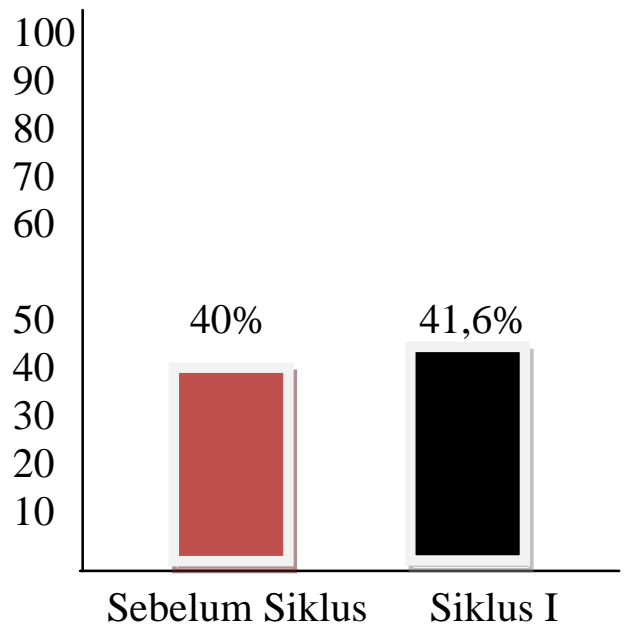

Gambar 1. Grafik penilaian hasil ketuntasan belajar

Hasil belajar tersebut belum mencapai target dari pembelajaran, sehingga dilanjutkan pada siklus II dengan melakukan refleksi terhadap proses pembelajaran siklus I, Setelah diadakan penelitian pada siklus II menunjukkan hasil bahwa kemampuan siswa dalam memahami materi pembelajaran menunjukkan adanya peningkatan. Sebelum siklus siswa yang mendapat nilai sesuai dengan standar ketuntasan minimal (SKM) hanya 3 siswa dari 9 siswa di SD Negeri 2 Gayau Sakti, sedangkan 
siswa yang lain mendapatkan dibawah SKM. Namun setelah diadakan perbaikan pada siklus II terjadi peningkatan yang begitu cepat. Peningkatan tersebut dapat dilihat dari Tabel 3, sebagai berikut:

Tabel 3. Daftar hasil belajar siswa kelas IV pada siklus I dan II

\begin{tabular}{|c|l|c|c|}
\hline No & \multicolumn{1}{|c|}{ Nama siswa } & $\begin{array}{c}\text { Nilai } \\
\text { siklus I }\end{array}$ & $\begin{array}{c}\text { Nilai } \\
\text { siklus II }\end{array}$ \\
\hline 1 & Ade Revaldo & 60 & 75 \\
\hline 2 & Ambar Puspi & 65 & 90 \\
\hline 3 & Aliya Rizki R. & 70 & 80 \\
\hline 4 & Bangkit & 65 & 65 \\
\hline 5 & Catur Aji P. & 80 & 70 \\
\hline 6 & Ivan Tama W. & 45 & 55 \\
\hline 7 & Meli Agustina & 50 & 75 \\
\hline 8 & Manda K. & 65 & 65 \\
\hline 9 & M.Tegar P. & 40 & 70 \\
\hline 10 & Nur Wahid & 65 & 65 \\
\hline 11 & Rizki A. & 75 & 70 \\
\hline 12 & Vircius C. & 65 & 70 \\
\hline 13 & Siti M. & 70 & 85 \\
\hline 14 & Sandi Pratama & 70 & 70 \\
\hline 15 & Nicolas G. N. & 65 & 65 \\
\hline 16 & Ajeng Dwi S. & 70 & 70 \\
\hline 17 & Suyatno & 70 & 70 \\
\hline
\end{tabular}

Ketuntasan kelas $=$ jumlah siswa yang tuntas x 100\% Jumlah total siswa

Ketuntasan kelas $=\frac{16}{17} \times 100 \%$

$$
=93,3 \%
$$

Dengan melihat tabel hasil belajar siswa dapat diketahui bahwa hasil belajar pada siklus II mengalami peningkatan yang cukup pesat yaitu 8 siswa sudah berhasil sesuai dengan SKM bahkan ada yang diatas SKM, hanya 1 siswa yang belum berhasil dari 9 siswa di SDN 2 Gayau Sakti.

\section{Pembahasan Siklus I}

Pada siklus I ini pengamatan yang diperoleh adalah:

a. Antusias siswa untuk mengikuti pembelajaran semakin meningkat, karena pembelajaran dengan metode penemuan lebih jelas dan terarah.

b. Interaksi antar guru dan siswa juga sering terjadi karena guru memperhatikan dan menghargai ide atau pendapat siswa.

c. Hasil akhir siklus pembelajaran ke I ini mengalami peningkatan yaitu $40 \%$ menjadi $41,6 \%$

\section{Pembahasan Siklus II}

Pada siklus II ini pengamatan yang diperoleh adalah:

a. Antusias siswa untuk mengikuti pembelajaran semakin meningkat, karena pembelajaran dengan metode penemuan lebih jelas dan terarah.

b. Interaksi antar guru dan siswa juga sering terjadi karena guru memperhatikan dan menghargai ide atau pendapat siswa. 
c. Hasil akhir siklus pembelajaran ke II ini semakin meningkat dibanding siklus I, dari rata-rata $41,6 \%$ menjadi $93,3 \%$

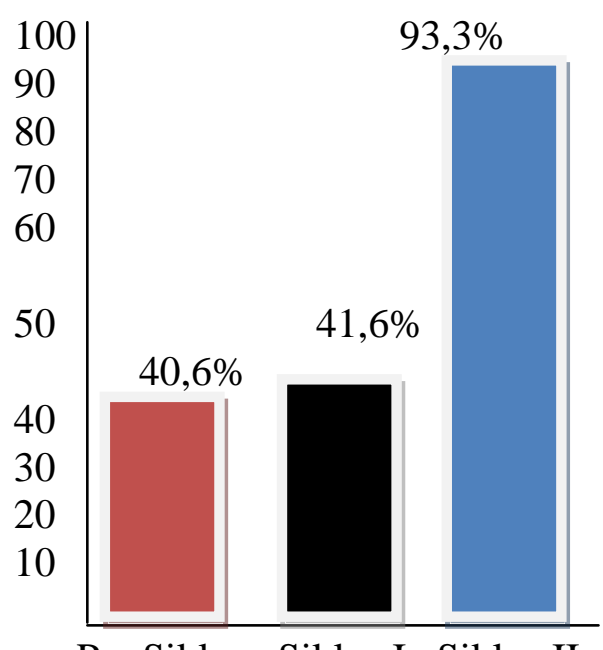

Pra Siklus Siklus I Siklus II

Gambar 2. Diagram grafik hasil pada pra siklus, siklus I \& II

\section{KESIMPULAN DAN SARAN}

Dari Penelitian perbaikan pembelajaran yang dilakukan peneliti dapat diambil kesimpulan sebagai berikut

1. Pembelajaran matematika dengan menggunakan model pembelajaran kooperatif tipe Make A Match dapat meningkatkan hasil belajar siswa

2. Pemahaman siswa terhadap materi pelajaran matematika dengan menggunakan model pembelajaran kooperatif tipe
Make A Match mengalami peningkatan

3. Dengan menggunakan model pembelajaran kooperatif tipe Make A Match dapat melatih dan mendorong siswa dalam menemukan suatu fakta atau relasi yang belum diketahui.

Dari kesimpulan di atas dapat disarankan hal-hal sebagai berikut:

1. Kegiatan pembelajaran matematika yang selama ini menggunakan metode ceramah kurang meningkatkan hasil belajar siswa, keaktifan siswa dan pemahaman terhadap materi sebaiknya menggunakan pembelajaran yang aktif, efektif, menyenangkan sesuai dengan situasi dan kondisi yang ada.

2. Dengan melihat hasil belajar siswa melalui model pembelajaran kooperatif tipe make a macht yang mengalami peningkatan, tentunya bisa dikembangkan dengan metode pembelajaran yang lain yang dianggap lebih efektif.

3. Dengan adanya perbaikan pembelajaran diharapkan dapat meningkatkan profesional guru dalam mengemban amanat sebagai guru yang profesional 


\section{DAFTAR PUSTAKA}

Arikunto, S. 2006. Penelitian

Tindakan Kelas. Jakarta:

PT Bumi Aksara

Fachrudin, I. 2009. Desain Penelitian Model

Pembelajaran Make A

Match. Malang.

Lie, A. 2003. Cooperative Learning.

Mempraktikkan

Cooperative Learning di Ruang-Ruang Kelas. Jakarta: PT. Grasindo.

Curran, L. 1994. Metode Pembelajaran Make A Match. Jakarta : Pustaka Pelajar.

Suyatno. 2009. Menjelajah Pembelajaran Inovatif. Bandung: $\quad$ Masmedia Buana Pustaka.

Undang-Undang No. 20 Tahun 2003 Tentang Sistem Pendidikan Nasional. 2007. Jakarta : Pustaka Indo Kerjasama Pokja Dikna DPP Partai Golkar

Wahab, A. A. 2007. Metode dan model-model mengajar IPS. Bandung : Alfabeta. 